\title{
A new species of Wygodasilus Artigas \& Papavero (Diptera, Asilidae, Asilinae) from Brazil
}

\author{
Rodrigo Vieira ${ }^{1}$, Freddy Bravo² \& Ivan Castro ${ }^{2}$
}

\begin{abstract}
'Programa de Pós-Graduação em Entomologia, Instituto Nacional de Pesquisas da Amazônia - INPA, Campus II, 69060-000 Manaus-AM, Brazil. Bolsista CNPq. rodrigo08vieira@gmail.com

${ }^{2}$ Programa de Pós-graduação em Zoologia, Departamento de Ciências Biológicas, Universidade Estadual de Feira de Santana, Av. Transnordestina s/n, 44036-900 Feira de Santana-BA, Brazil. ifcastro@yahoo.com.br; fbravo@uefs.br.
\end{abstract}

\begin{abstract}
A new species of Wygodasilus Artigas \& Papavero (Diptera, Asilidae, Asilinae) from Brazil. The second species of the Neotropical genus Wygodasilus Artigas \& Papavero, 1995, Wygodasilus albisetus sp. nov., is described from Bahia state, Brazil. The habitus, wing, male and female terminalia are described and illustrated.

KEYWORDS. Eichoichemus-group; Neotropical; Taxonomy.

RESUMO. Uma nova espécie de Wygodasilus Artigas \& Papavero (Diptera, Asilidae, Asilinae) do Brasil. A segunda espécie do gênero Neotropical, Wygodasilus Artigas \& Papavero, 1995, Wygodasilus albisetus sp. nov., é descrita para Bahia, Brasil. São fornecidas descrições e ilustrações do hábito, asa e terminálias masculina e feminina.
\end{abstract}

PALAVRAS-CHAVE. Grupo Eichoichemus; Neotropical; Taxonomia.

The genus Wygodasilus Artigas \& Papavero, 1995 (type species W. pulchripes (Bromley, 1928), type locality Piedra Blanca, Bolivia) was included in the Eichoichemus-group of Asilinae with Eichoichemus Bigot, 1857 and Proctophoroides Artigas and Papavero, 1995 (Artigas \& Papavero 1995). The type species of Wygodasilus is known only by the holotype male. In this paper, we described the second species of the genus from the sand dunes of the middle São Francisco River, northeastern Brazil.

\section{MATERIAL AND METHODS}

This study is based on the examination of specimens housed in the following Brazilian institutions: Coleção Entomológica Prof. Johann Becker do Museu de Zoologia, Universidade Estadual de Feira de Santana, Feira de Santana, Bahia (MZUEFS) and Instituto Nacional de Pesquisas da Amazônia, Manaus, Amazonas (INPA). Morphological terminology follows Cumming \& Wood (2009). Detached wings were mounted on microslides in Canada. The microslides were glued on the edge of a piece of resistant paper and thereafter, attached at the same pin of the specimen. In this way, the piece is maintained detached next to the specimen. Dissected terminalia were treated in hot $\left(40^{\circ} \mathrm{C}\right) 10 \% \mathrm{KOH}$ for 8 hours, washed in water, then treated in $10 \%$ acetic acid and examined in excavated slides in glycerin. After examination and illustration, the detached parts were placed in microvials with glycerin and pinned with their respective specimens.

The label data are cited in full, with the original spellings, punctuations, and dates. Information presented within square brackets is complementary data not included on the labels. Data for the same specimen but from different labels are separated by slashes (/). The map (Fig. 1) was built with DIVA-GIS 7.4.0.

\section{RESULTS}

\section{Wygodasilus Artigas \& Papavero, 1995}

Wygodasilus Artigas \& Papavero, 1995: 99. Type species: Erax pulchripes Bromley, 1928 (orig. des.).

Comments. The presence of a short stump vein on vein $\mathrm{R}_{2+3}$ (Fig. 4) in Wygodasilus differentiates this genus from the other two genera of Eichoichemus-group, Eichoichemus and Proctophoroides (species with a complete extra vein that unites vein $\mathrm{R}_{4}$ with $\mathrm{R}_{2+3}$ ). Furthermore, differs from Proctophoroides by having obtuse claws. Bromley (1928) when described $W$. pulchripes cited as type locality Piedra, Brazil, however, this locality refers to Piedra Blanca, Santa Cruz, Bolivia (4 miles west of Corumbá, Mato Grosso do Sul, Brazil) (Martin \& Papavero 1970; Artigas \& Papavero 1995).

\section{Wygodasilus pulchripes (Bromley, 1928)}

Erax pulchripes Bromley, 1928: 4.

Nerax pulchripes; Hull, 1962 (2): 478.

Efferia pulchripes; Martin \& Papavero, 1970: 67 (catalogue).

Wygodasilus pulchripes; Artigas \& Papavero, 1995: 99; Papavero, 2009: 27 (catalogue).

Diagnosis. Mystacal macrosetae and lower occipital setae golden; apical scutellar setae black. Fore coxae with golden or pale setae. Femora shining black contrasting sharply 


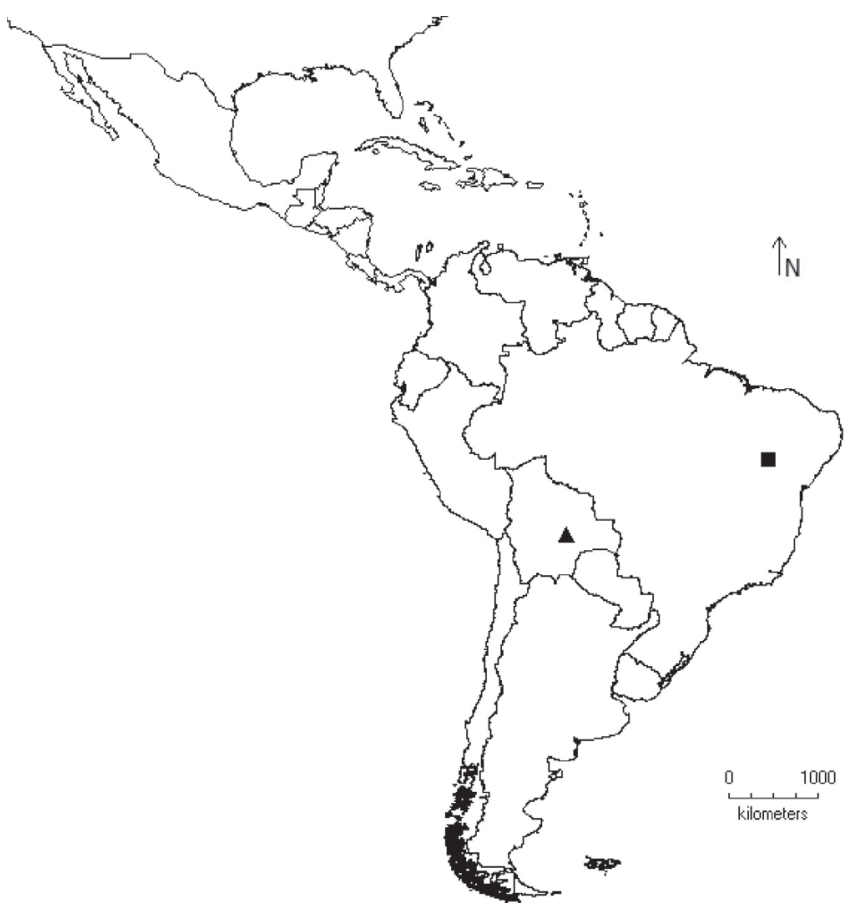

Fig. 1. Distribution map of Wygodasilus species: W. albisetus Vieira, Bravo \& Castro, sp. nov. (square) and W. pulchripes (Bromley, 1928) (triangle).

with the yellow of the tibiae. Tarsi, tip of posterior tibiae, and a line on inner side of median and anterior tibiae black. Sternite VIII with black setae. Male terminalia reddish brown.

\section{Wygodasilus albisetus sp. nov.}

(Figs. 2-16)

Diagnosis. Mystacal macrosetae mostly whitish and with 9 black macrosetae, lower occipital setae white; apical scutellar setae white. Fore coxae with white setae. Leg mostly brown. Sternite VIII with white setae. Male terminalia yellow to light brown (Fig. 5).

Male holotype (Figs. 2-13). Size: body length $11.5 \mathrm{~mm}$. Head. Scape and pedicel dark brown, postpedicel dark brown with yellow base; 2 ocellar setae and 2 macrosetae; vertex gray tomentose; face gray tomentose; mystacal macrosetae mostly whitish and with 9 blackish macrosetae; frons gray; occiput gray tomentose; occipital setae whitish; 3 black postocular macrosetae; palpus brown setose with some whitish setae on base; labial setae yellowish; proboscis black with whitish ventral setae.

Thorax (Figs. 2, 3). Antepronotum and postpronotum light brown, gray and golden tomentose; mesonotum black, except light brown region above postpronotal lobe, mesonotum golden tomentose, lateral area of mesonotum, prescutellar region and scutellum grayish; paramedian stripe, presutural and postsutural spot black; pleuron mostly light brown, gray tomentose, katepisternum and meron + metanepisternum partially black. Chaetotaxy: 2 black notopleural macrosetae; 2 black supralar macrosetae; 1-2 black postalar macroseta;
4 black presutural pairs of dorsocentral setae and 4 black postsutural pairs macrosetae; setae on posterior scutum between dorsocentral setae whitish; 2 whitish apical scutellar macrosetae; discal scutellar setae whitish; no anatergal seta; katatergal macrosetae whitish; setae on posterior meron + metanepisternum whitish.

Wing (Fig. 4). Wing length $6.7 \mathrm{~mm}$. Hyaline to slightly brownish. No costal dilation; $\mathrm{R}_{4}$ and $\mathrm{R}_{5}$ bifurcation placed beyond discal cell apex; crossvein $\mathrm{r}-\mathrm{m}$ situated beyond middle of discal cell; short stump vein supernumerary crossvein on $\mathrm{R}_{4}$ not reaching base of $\mathrm{R}_{2+3}$; microtrichia on posterior wing margin arranged in a single plane; halter yellow.

Legs. Fore coxae brown; mid and hind coxae brown with mixed black. Fore femora dark brown anteriorly, yellow to light brown dorsally and posteriorly; mid femora dark brown anteriorly, brown dorsally and posteriorly; hind femora dark brown anteriorly and dorsally, brown posteriorly; fore and mid tibia brown anteriorly and dorsally, light brown posteriorly; hind tibia dark brown anteriorly and dorsally and light brown posteriorly; all tarsomeres brown, claws obtuse. Chaetotaxy: fore coxae with white setae; all femora with white setae ventrally; mid femur with one black macroseta anteriorly and 4 black anteroventrally, 1 black posterodorsal apical macroseta; hind femur with 1 black anterodorsal preapical macroseta, 2 black anterior macrosetae, 1 anteroventral basal whitish and 3 anteroventral black macrosetae, 4-5 white macrosetae posteroventrally; fore tibiae with 4-5 black setae dorsally, 2 whitish macrosetae and 2 black macrosetae posteriorly on the left leg and 1 whitish macrosetae and 3 black macrosetae on the right leg; mid tibiae with 3 whitish macrosetae posteroventrally and 1 whitish lateroapical; hind tibiae with 4 black macrosetae anterodorsal and 2 black basal setae posterodorsal. All setae of tarsomeres black.

Abdomen (Figs. 2, 3). Apical half of tergite I gray tomentose and basal half blackish, tergite I with whitish macrosetae laterally; tergites II-V black dorsally and with gray tomentose subtriangular spot laterally; tergites VI-VII grayish tomentose; setae on apical margin of sternite VIII whitish.

Terminalia (Figs. 5-13). Yellow to light brown (Fig. 5). Terminalia erect, positioned perpendicular to the abdomen (Fig. 2); epandrium separated proximally and joining proximomedially (Fig. 7); epandrium tapered until apex (Figs. 5, 8); apex podiform (Figs. 5, 8); hypandrium reduced, mainly medially (Fig. 5, 8); gonocoxite inverted comma shaped (Fig. 9); gonocoxal apodeme narrow in lateral view (Fig. 9); inner margin of gonocoxite with black setae (Fig. 9); apex of gonostylus wider than base with setae medioapically (Figs. 9, 10); ejaculatory apodeme long and wide proximally in lateral view (Fig. 11); phallus with wing-shaped projection on each side next to prongs (Figs. 11, 12); phallus with 3 prongs; subepandrial sclerite with a subretangular projection with a medioapical margin v-shaped (Fig. 13).

Female (Figs. 14-16). Similar to male except body length: $11.1 \mathrm{~mm}$, wing length: $6.8-7.0 \mathrm{~mm}$, face gray and golden tomentose; mystacal macrosetae mostly whitish with 9-10 

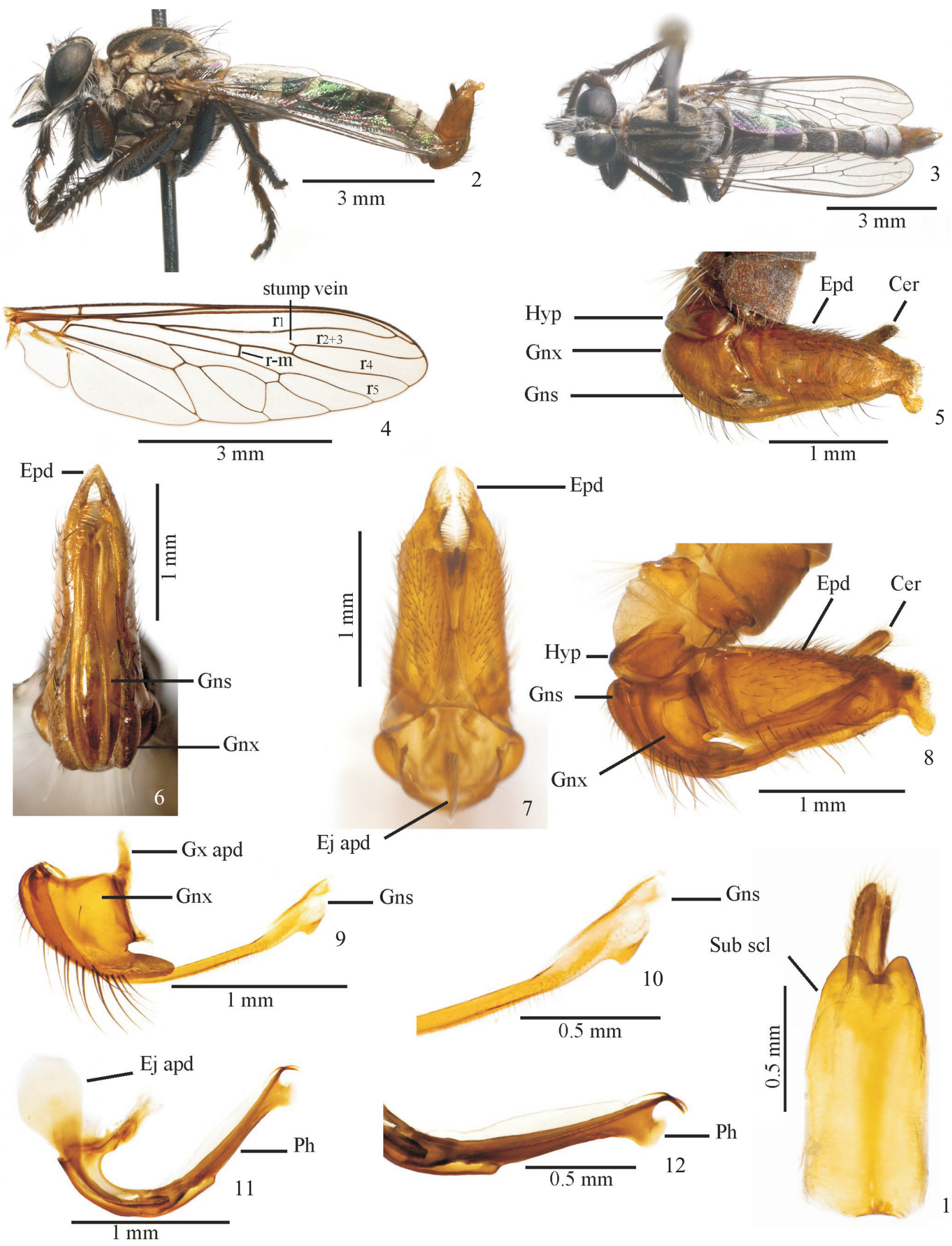

Epd

7

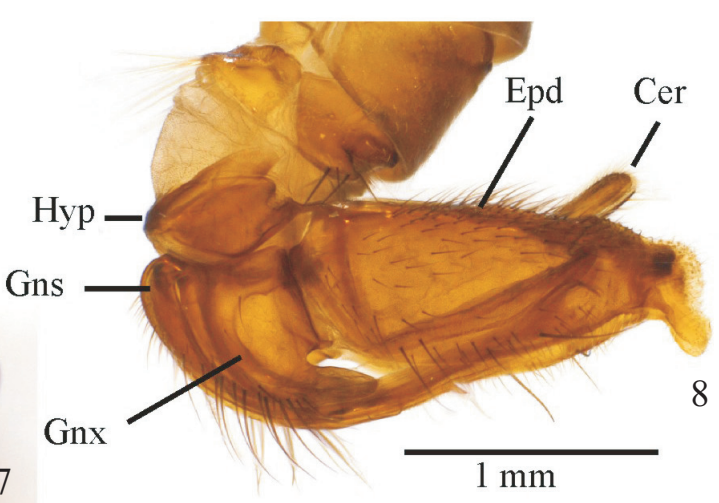

10

Sub scl

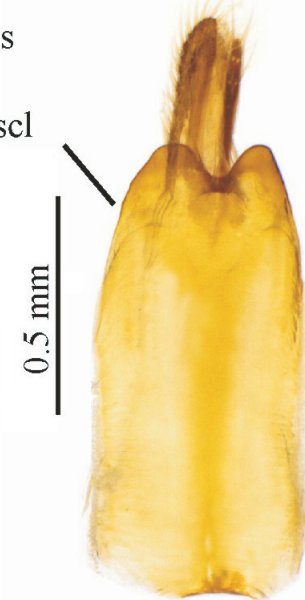

Figs. 2-13. Wygodasilus albisetus Vieira, Bravo \& Castro, sp. nov., male: 2, habitus, lateral view; 3, habitus, dorsal view; 4, wing; 5, male terminalia, lateral view; 6, male terminalia, ventral view; 7, male terminalia, dorsal view; 8 , male terminalia in lateral view treated in hot $10 \% \mathrm{KOH}$; 9 , gonocoxite and gonostylus; 10, apex of gonostylus; 11, phallus and ejaculatory apodeme, lateral view; 12, apex of phallus; 13, subepandrial sclerite. Abbreviations: Cer: cercus; Ej apd: ejaculatory apodeme; Epd: epandrium; Gnx: gonocoxite; Gns: gonostylus; Gx apd: gonocoxal apodeme; Hyp: hypandrium; Ph: Phallus; Sub scl: Subepandrial sclerite. 


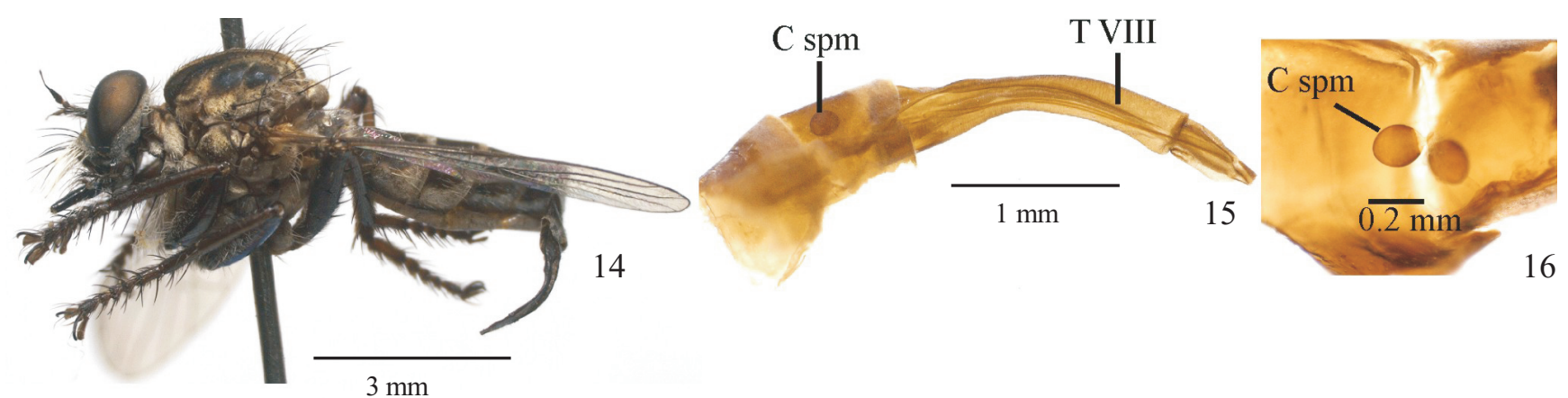

Figs. 14-16. Wygodasilus albisetus Vieira, Bravo \& Castro, sp. nov., female: 14, habitus, lateral view; 15, ovopositor, lateral view; 16, capsule of spermathecae. Abbreviations: C spm: Capsule of spermathecae; T VIII: Tergite VIII.

blackish macrosetae; 3 black and 1 whitish postocular macrosetae; 1-2 black and 1 whitish postalar macrosetae on the left side and 1 black and 1 whitish on the right side; 4-5 black postsutural pairs macrosetae; hind tibia brown; hind femur with 3 black or 2 black and 1 white anterior macrosetae, 4 black anteroventral macrosetae, 4 whitish macrosetae posteroventrally; fore tibiae with 5 black setae dorsally, 4 black macrosetae posteriorly; mid tibiae with 3 whitish macrosetae or 4 black macrosetae posteroventrally; hind tibiae with 2-3 black anterodorsal macrosetae; tergites VI-VII 1/3 distally grayish; tergite VIII long (Fig. 15); ovipositor brown; 3 oval capsules of spermathecae (Figs. 15, 16); capsules of spermathecae sclerotized, except narrow base (Fig. 16).

Etymology. From the latin albis $=$ white, seta $=$ bristle. It makes allusion to the white scutellar macrosetae.

Type material examined. Holotype Ơ: BRASIL, BA[hia], Pilão Arcado, Barra dos Brejos, Zacarias, UTM: 615832/8622488; [1007'30"S 042²2’21”W], 04.xii.2005 Vieira, R. \& Alvim, E./MZUEFS \# 8942/Holótipo (ণ') Wygodasilus albisetus Vieira, Bravo \& Castro (MZUEFS). Holotype condition: Right antennae, and left flagellum and stylus glued on the label; 1 ocellar macroseta lost; detached wing mounted on microslide, terminalia placed in microvial with glycerin and pinned along with the specimen.

Paratypes: 1 \% same locality, data and collectors as holotype, except (INPA); 19 same locality, data and collectors as holotype, except MZUEFS \# 8939, abdomen missing (MZUEFS).

Type locality. Pilão Arcado is a Municipality located on the Quaternary sand dunes of the middle São Francisco River, northern Bahia State, Brazil. A description and the biological importance of this area can be found in Bravo et al. (2009).

\section{ACKNOWLEDGMENTS}

To Fundação de Amparo à Pesquisa do Estado do Amazonas (FAPEAM) and Conselho Nacional de Desenvolvimento Científico e Tecnológico $(\mathrm{CNPq})$ for the financial support to the Project PRONEX (Edital 016/2006, Proc. 1437/ 2007); to PPBio- Programa de Pesquisa em Biodiversidade do Semi-árido/MCTI for the financial support and CNPq for the fellowships that have allowed us to complete this work.

\section{REFERENCES}

Artigas, J. N. \& N. Papavero 1995. The American genera of Asilidae (Diptera): Keys for identification with an atlas of female spermathecae and other morphological details. IX.3. Subfamily Asilinae Leach, Eichoichemus group, with the proposal of two new genera and a catalogue of the Neotropical species. Gayana (Zoologia) 59: 97-102.

Bravo, F.; H. Pohl; A. Silva-Neto \& R. G. Beutel 2009. Bahiaxenidae, a "living fossil" and a new family of Strepsiptera (Hexapoda) discovered in Brazil. Cladistics 25: 614-623.

Bromley, S. W. 1928. New Neotropical Erax in the American Museum of Natural History (Diptera: Asilidae). American Museum Novitates 334: 1-5.

Cumming, J. M. \& D. M. Wood. 2009. Adult morphology and terminology, p. 9-50. In: B. V. Brown; A. Borkent; J. M. Cumming; D. M. Wood; N. E. Woodley \& M. A. Zumbado (eds.). Manual of Central American Diptera. Volume 1. Ottawa, National Research Council Research Press, 950 p.

Hull, F. M. 1962. Robber Flies of the World: The Genera of the Family Asilidae. Bulletin of the United States National Museum, Part 2, 224: 431-907.

Martin, C. H. \& N. Papavero. 1970. 35b. Family Asilidae. In: N. Papavero (ed.). A catalogue of the Diptera of the Americas south of the United States. São Paulo, Museu de Zoologia, Universidade de São Paulo. 139 p. Papavero, N. 2009. Catalogue of Neotropical Diptera. Asilidae. Neotropical Diptera 17: 1-178. 